\title{
RUTGERS' 1870 CENTENNIAL CELEBRATION AND OTHER CHARTER-RELATED PUZZLES
}

\author{
BY CARYN RADICK \\ cradick@rulmail.rutgers.edu
}

\section{Introduction}

By the time this article is published, Rutgers will be in the midst of celebrating its 250th anniversary. As an archivist at Rutgers Special Collections and University Archives, I have been aware of the approaching 250th for the last decade, as my colleagues have worked to ensure that Rutgers' history is shared and celebrated. Thanks to institutional memory and access to archival resources, I know that the 150th and 200th anniversaries in 1916 and 1966 were similarly marked with planning and celebrations. And of course, the centennial of Rutgers' founding (as Queen's College) was celebrated as well. "Traveling" through the archives, however, revealed something a little different about the 100th anniversary celebration at Rutgers, especially in light of the preparations for 2016.

The Rutgers centennial was celebrated in the wrong year1870.

This article will discuss the "mistiming" of the centennial, and detail research into how, when, and by whom the discovery of the correct founding date was made. As Rutgers' Charter Day (November 10 ) is a celebration of that "original" founding date in 1766, this article will explain its origins and discuss some of aspects of its celebrations. Finally, it will conclude with a discussion about how Rutgers acquired a contemporaneous copy of its second charter, which was granted by Royal Governor William Franklin in 1770.

\section{The Rutgers Centennial}

In 1866, no one knew about the original November 10, 1766 charter by which Governor Franklin brought Queen's College into existence-consequently, the actual centennial came and went without acknowledgement or celebration. Instead, the Rutgers community believed that the second charter of 1770 was the http://dx.doi.org/10.14713/irul.v68i1.1951

The Journal of the Rutgers University Libraries, Volume 68, pp. 1-18.

(i) (\$) JRUL is licensed under a Creative Commons Attribution-NoncommercialNoDerivs 4.0 United States License. 
founding document, and thus celebrated the centennial in 1870 . This event was covered in the student newspaper, the Targum, and the New York Times, the latter of which gave a detailed account, mentioning the "delightful weather," the attendance of the present and three former governors of New Jersey, and the proceedings of the day. It summarized the history of Rutgers, "The institution was chartered at the instance of the Dutch Reformed Church in the Province of New-Jersey, in the year 1770, and received the name Queen's College which it sustained until 1825."1

In a speech nearly 40 years later-marking the 1908 Charter Day-Rutgers President William Henry Steele Demarest discussed the lack of knowledge of Queen's founding and of learning the correct date:

We have no copy of the 1766 charter. In fact not until quite recent years was it known that such a charter had been granted; and the centennial of the college was celebrated in 1870, one hundred years from the granting of the second charter; at that time, however, the question had arisen whether a charter surely prepared prior to 1770 had prior to that time received the great seal, the government sanction. That there had been such grant, with the date of granting, plainly appears in an announcement printed in New-York Mercury of April 20 and April 27 and May 4, 1767... ${ }^{2}$

Sixteen years later, in his book The History of Rutgers College (1924), Demarest displayed a rather sanguine attitude towards the centennial date; it simply happened that way-and besides, it did not really matter.

The year 1870 has its unique stone of remembrance in its celebration of the centennial of the college, Queen's College. It is now known as four years after date. It seems strange, when the facts of the founding are now so familiar, that so long after the founding and so far on in the 19th century there should have been any unfamiliarity with the first charter and its time. Yet that charter was unknown or was given no importance. No one had entered into the search of historical sources in adequate [sic] way. The charter of the college to the 
men of 1870 or of 1866 was the charter of 1770 and the college centennial would be the hundredth anniversary of that. Moreover, it may fairly be added that such time would be nearer the centennial of the actual start of the college's work, for the work did not start until 1771. Still further it may be said that the exactness of anniversary time is far less important than the interest and achievement of anniversary celebration.... ${ }^{3}$

Despite Demarest's last qualification, anniversary celebrations subsequent to the date's discovery have reflected the correct year of founding.

\section{Correction of the Record}

The question of how the correct date of Rutgers' founding was determined is not straightforward-thus far I have not found a "eureka" document indicating discovery or much by way of an announcement. However, a few sources attribute the discovery to Austin Scott, a Rutgers history professor from 1883 to 1891 and president of Rutgers from 1891 to 1906 . Both the Targum and New York Times relate Scott's discovery, with mention of him finding the calls in the New-York Mercury-alluded to in Demarest's speech above-that helped determine the proper date. The New York Times gave a detailed account in 1895 :

Until within a few years, the true history of the founding of Rutgers College was unknown. It was believed that the college began its life in 1771 and in 1871 the centennial of the institution was celebrated. Dr. Austin Scott, President of the College, has made a careful search for documents which might shed more light on its early history. This search has been rewarded with unexpected success.

In several copies of The New-York Mercury published in 1767, Dr. Scott found a call for a meeting of the Trustees of the college, then known as Queens College, to be held on May 2 of that year. In this call, it was stated that on Nov. 10, 1766, Queens College was granted the charter by Gov. William Franklin. These papers, faded and moldering with their great age, are still in existence. ${ }^{4}$ 
Although this article got the basics right, the 1871 date is off by a year (although as Demarest mentioned, the work did indeed begin in 1771). The article makes another error that will be addressed later. As far as the attribution of the discovery of the correct year to Scott, I suspect it is not quite an error, but a conflation of events in how the discovery took place. My reasoning for this conclusion is that five years before this article was written, Scott acknowledged learning about 1766 from someone else.

Scott's attribution occurred in 1890 in correspondence with the University Magazine. ${ }^{5}$ Two letters to the editor appeared in the February 1890 issue. The first letter was from F. Reid Miller, Rutgers Class of 1891 and editor of the Targum, whose letter appeared under the headline "The Recently Discovered Charter of Rutgers." The letter was dated February 7, 1890, and addressed to University Magazine editor James Wilton Brooks:

Dear Sir:-The establishment of Rutgers College, originally called Queen's College, has usually been dated from a royal charter of 1770 . In a recent investigation, Prof. Austin Scott, PhD, discovered that "His Royal Majesty's Letters Patent and Charter or Royal Grant for Queen's College was secured from His Excellency, William Franklin, Esq., Governor and Commanderin-Chief in and over the Province of New Jersey, on November 10, 1766..." 6

This letter was followed by one from Austin Scott, which suggests Brooks contacted him seeking verification of the founding date. Scott wrote:

Mr. Miller is quite right in his statements, save in his assigning credit to me for discovering the fact of the granting of the first charter of Rutgers College (then Queen's), on November 10, 1766. My "discovery" was simply of original documents which confirmed our knowledge of the fact and emphasized so strongly the right of the college to take as the true date of the founding, November 10, 1770, the date of the second charter, that henceforward the college will print the date of its founding, 1766. It is so printed in the current catalog and is to be carved in stone on the front of the new dormitory. ${ }^{7}$ 
Scott, reflecting his training as a historian, went on to name the source (down to the pages, no less) he was able to verify.

Rev. Dr. [David] Demarest in his "History of the Centennial of the Seminary of the Reformed Church in America," pp. 70 and 332 states the fact of the grant of the first charter to Queen's College by Gov. William Franklin as well the call published in the New-York Mercury of April 20, 27, and May 4, 1767 for a meeting of the trustees of Queen's College under the Charter of November, $1766 .^{8}$

Indeed, checking Centennial of the Theological Seminary of the Reformed Dutch Church in America verifies that it gave the first Queen's charter granting date as November 18, 1766 and printed the calls from the New-York Mercury that refer to November 10, 1766. ${ }^{9}$ David Demarest also discussed the petition for and granting of the second charter, along with some of its contents. ${ }^{10}$

Centennial was published in 1885, meaning that there was a lag between its assertion and its revelation at Rutgers. Based on Scott's letter and the other reports, he may have wanted to do further investigation and see the calls in the New-York Mercury for himself before supporting Demarest's statement of dates. Scott was also able to track down the 1769 petition, which asked for a change to the 1766 charter, ultimately leading to the 1770 version. This would also have assured him of the existence of the earlier charter.

As to why Miller wrote to University Magazine, he may have been prompted by a listing ("Register") of colleges that appeared in every issue. Where the February 1890 issue listed Rutgers as founded in 1770, placing it after Dartmouth, the issue in which his and Scott's letters appeared showed Rutgers listed above Dartmouth, with the founding date of 1766 . It is possible that seeing the first listing, Miller felt the need to send in a correction. ${ }^{11}$

Because of the lack of information in the records, it is difficult to determine exactly when the discovery of the correct date was made, albeit it would seem to be between 1870 and 1885. As far as when the correct date became known and taken up at Rutgers, the June 1889 issue of the Targum alludes to "the latest records discovered by Dr. Scott" leading to knowledge of November 10, 1766 as the founding date. ${ }^{12}$ Rutgers' publications such as the Catalog and Scarlet Letter yearbook give the founding year as 1770 . 
The founding year changes to 1766 in the 1888-1889 Catalog and the 1890 yearbook (which came out in 1889). ${ }^{13}$ Thus, it appears that after verifying the dates from Demarest's book, Scott began to promote the use of the correct year and was consequently credited as its discoverer.

\section{Charter Day}

Although the discovery of the founding date became "official" in 1888, it was not until 1895 that Rutgers began to celebrate the anniversary of the granting of the charter as Charter Day. This section will examine the evolution of Charter Day and how it was celebrated at Rutgers.

One instrumental factor in the inauguration of the Charter Day tradition was Austin Scott's appointment as president of Rutgers in 1891. However, Charter Day was first suggested in 1889. The same issue of the Targum that noted Scott's "discovery" had an article suggesting that Rutgers should have a "special" day that commemorated its history. The authors felt that the students could use a holiday and "such a day, we feel sure would prove to be both pleasurable and advantageous."

"Why cannot Rutgers have an especial day commemorative of some eminent event in her history, set apart as a holiday distinctively her own and as the particular Rutgers Day," the article asks, pointing out that other colleges and universities have such "special" days.

Because the routine of a century has not been broken by one, strongly urges its adoption. Certainly the history of the college affords ample liberty in this selection. For instance, on November 10, 1766, the charter of the institution under the name of Queen's College, was granted. Why not call that 'Charter Day,' and celebrate it accordingly? ${ }^{14}$

The authors suggested other days such as November 30 as "Rutgers Day" (for the day the name was changed from Queen's 
to Rutgers) and May 7, when the college site was fixed at New Brunswick. They suggest a celebration of Founders Day in May, "a month of sunshine and flowers, of balmy air and moonlight nights. No time could be more suitable for celebrating the founding of old Rutgers." They continued to promote the idea as beneficial to Rutgers. "Pleasure and profit could be combined in its celebration. It is customary on such an occasion to have some distinguished speaker present, and such a man is likely to be mentioned in the papers, thereby attracting attention to the institution. ${ }^{15}$

Although much of what the authors said about having a Rutgers-based celebration proved to be true, the observance of such a holiday was not taken up for more than five years.

The first Charter Day itself appears to have been organized quickly. One of the few mentions of planning I could find was in the Rutgers Faculty Minutes for September 30, 1895, which recorded: "The President called to the attention of the Faculty to the fact that the 129th anniversary of the founding of the College will fall on Sunday, November 10th, 1895 and suggested that arrangements be made for an appropriate observation of 'Charter Day.'"16

The Targum of November 6, 1895 then carried an announcement of the celebration, indicating that it would be more religious in tone because November 10 fell on a Sunday that year, but would be more of a holiday in subsequent years.

The first Charter Day was a major celebration (albeit with bad weather in contrast to the centennial of 1870), taking place in Kirkpatrick Chapel with speeches and even a special Charter Day hymn written by Professor William Rankin Duryee (sung to "Meribah"). ${ }^{17}$ Austin Scott spoke about the founding of the college, noting how the 1770 charter was the result of the trustees petitioning for a change to the initial charter. ${ }^{18}$

It was this occasion for which the New York Times report with the date errors discussed earlier appeared. Along with the claims of Scott finding the calls in the New-York Mercury, the paper reported that "a copy of the charter as amended in 1769 is now in Dr. Scott's possession." However, this is a mistake or misunderstanding. At this point in time, Rutgers did not possess a copy of the original nor the 1770 charter (although it is clear that the contents of the latter were known). Looking at Scott's writings and papers, this claim appears to refer to the 1769 petition that brought about the 1770 charter. Scott alluded to the differences between the two charters 
being a "distinction." "The real difficulty however in setting Queens College at once at work sprang out of a clause in the charter which the trustees said made an 'alarming distinction' between residents of the Province of New Jersey," and that "the exact nature of this distinction is not clear." 19 This language is pulled from the 1769 petition, which indeed uses the "alarming distinction" phrase in reference to an issue of residency. ${ }^{20}$ Given some of the complications of the story, it is plausible that the New York Times understood the original petition for a new charter to be the new charter itself.

The Targum remarked of the first Charter Day, "It is hoped that the anniversary observance thus happily inaugurated may not be allowed to lapse, but that with each succeeding year may witness its celebration of Charter Day." ${ }^{21}$ The Targum continued reporting on subsequent Charter Days over the following years, although it was marked in a quieter manner on those November 10ths that fell on weekends.

Charter Day celebrations also reflected the changes in the college. In 1896 it was celebrated in the recently-built Ballantine Gym. In 1899, the Targum noted that the tradition was to mark Charter Day a little bit differently every year. In that year, the occasion was used to open a new historical room and for the presentation of Henry Janeway Weston Memorial Collection..$^{22}$ In 1902, the Targum noted the occasion was marked with a bright scarlet banner floating over "our oldest and best beloved building, Queens." ${ }^{23}$ Despite the proclamation of doing something different every year, the 1904 Charter Day was "duly celebrated in accordance with the usual form, in Kirkpatrick." 24

\section{Charter Day and Acquisition of the 1770 Charter}

Austin Scott resigned as president and rejoined the Rutgers faculty in 1906. The one-page Targum article marking this change made no mention of the discovery of the date of the first charter, nor the implementation of a day celebrating it when discussing his achievements. ${ }^{25}$

Scott was succeeded as president by William Henry Steele Demarest, son of David D. Demarest. After several more subdued celebrations of Charter Day, it once again became a large and grand occasion on Rutgers' 142nd anniversary in 1908. The Targum of November 11, 1908 reported that the governor of New Jersey, the mayor of New Brunswick, and President Demarest all spoke. During 


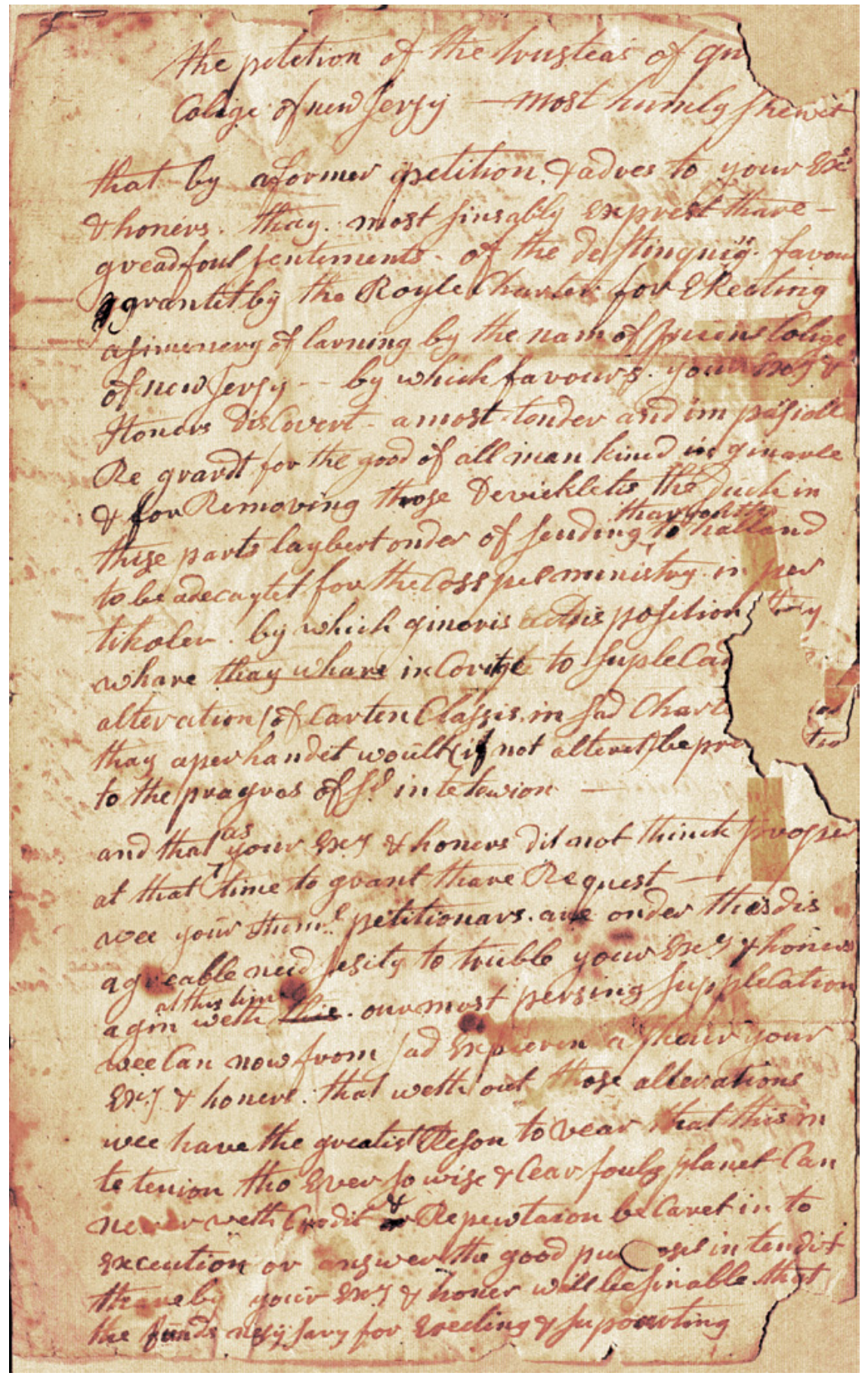

First page of 1769 petition 
the celebration, Demarest gave a speech about the history of Rutgers and the charter. ${ }^{26} \mathrm{He}$ mentioned that the 1766 charter had never been found, which remains true in 2016, and that Rutgers had only recently acquired the 1770 charter:

While no copy whatever of the 1766 Charter is in our possession, the college is peculiarly fortunate in having a copy of the 1770 Charter, printed in the very year of its granting. I hold in my hand that original printing and at the same time an exact reproduction of which a limited number have been made. Until very recently we had no printing of the document, bearing date earlier than $1810 . .^{27}$

As to how the charter was acquired, Demarest said:

Two or three years ago our Librarian received a letter from a dealer in New York who stated that, having acquired the Library of a certain Dr. Purple, lately deceased, he had found in it a copy of the Queens College Charter, printed in 1770, that he would offer it to Rutgers College for fifty dollars. Of course the college at once purchased it. ${ }^{28}$

This statement raises two questions. The first is why was 1908 the year Rutgers celebrated receiving this charter when it had been at Rutgers for two or three years? The second question is who was this intriguingly-named Dr. Purple and why did he have the only known print? Demarest was silent on the first issue in his speech, but of the latter said:

Purple had been unknown to our college people. Probably he had no particular relation with the College. He was a collector of rarities, of old books, and of fine printings; and he had secured this for his collection, no doubt, simply as a beautiful piece of printing by a famous printer. ${ }^{29}$

Demarest had written to the dealer, Francis Harper, inquiring about Purple, but I have not found a response in the archives. In describing Dr. Purple, Demarest was only partly correct. Dr. Samuel 
Smith Purple was a medical doctor, the head of the New York Society of Medicine and the founder of its library. More pertinent to his possession of the charter, he was the author of several bibliographic and genealogical works about the Dutch Reformed Church, particularly in New York. Presumably, the actual details of the 1770 charter founding a Dutch Reformed based-school would have appealed to him along with the printing and printer. ${ }^{30}$

As to the reason for the lag between the acquisition of the charter and its celebration, part of the answer lies in the timing. Although it is not clear when Harper contacted Rutgers, the charter was not received until late November 1906, after the Charter Day celebration that year. This charter, which is now held in the University Archives, contains a letter bound into it from Harper, dated November 26, 1906, indicating that charter was on its way by special courier and that "we are glad you are able to secure this volume as it really
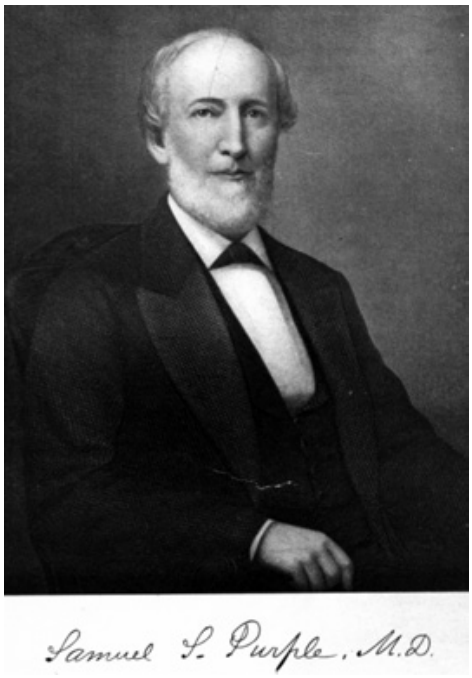

Dr. Samuel Smith Purple. From The Catalogue of the Genealogical Library of the Late Samuel S. Purple, M.D.... belongs to your college." ${ }^{31}$ The Targum of December 12, 1906, carried a story about the acquisition, but it was otherwise not discussed. In 1907, Charter Day fell on a Sunday, and the Targum reported, "It being Sunday, a distinct celebration was omitted, but at the regular Chapel service the Charter Day hymn was sung and a special sermon was preached by Dr. Edward P. Johnson of the New Brunswick Theological Seminary." ${ }^{\prime 2}$ Thus in keeping with previous weekend Charter Days, 1907 was a quiet affair. In 1908, November 10 fell on a Tuesday, a day more suitable for a large celebration.

\section{Impacts of the Charter}

The acquisition of the 1770 charter spurred two different actions. The first was a renewed interest in finding the 1766 charter. The University Archives has letters to Demarest and Osborn from Augustus Shearer, Rutgers Class of 1899, who looked for the charter in Europe and from Anna M. North, a Trenton, New Jersey-based 
genealogist who concentrated on searching in New Jersey and New York. At one point North was actually misled to believe the first charter had been found, but in writing to obtain a copy of it, learned that her informant was referring to the recently-discovered second charter. ${ }^{33}$ Their searches were unsuccessful and in learning of the charter confusion, North wrote: "Now I must confess I feel baffled, and do not know what further to do for thee...I have just discovered a charter for a Library in Burlington... and I wish I could find what thee wishes." 34 Over the years, North's sentiments have been echoed by several other "searchers," including University Historian Richard P. McCormick.

The second impact of the acquisition of the 1770 charter was the administration's decision to make copies to sell to the Rutgers community. Professor Edward L. Stevenson arranged for the copies and in April 1907 advertisements were sent announcing the acquisition of the charter and letting the recipients know of the availability of reproductions. "A handsome fac-simile of this very artistic old print, bound in scarlet morocco and stamped with title and the College seal...may be obtained at a cost covering merely the price of reproduction-Three Dollars and Fifty Cents." ${ }^{\prime 35}$

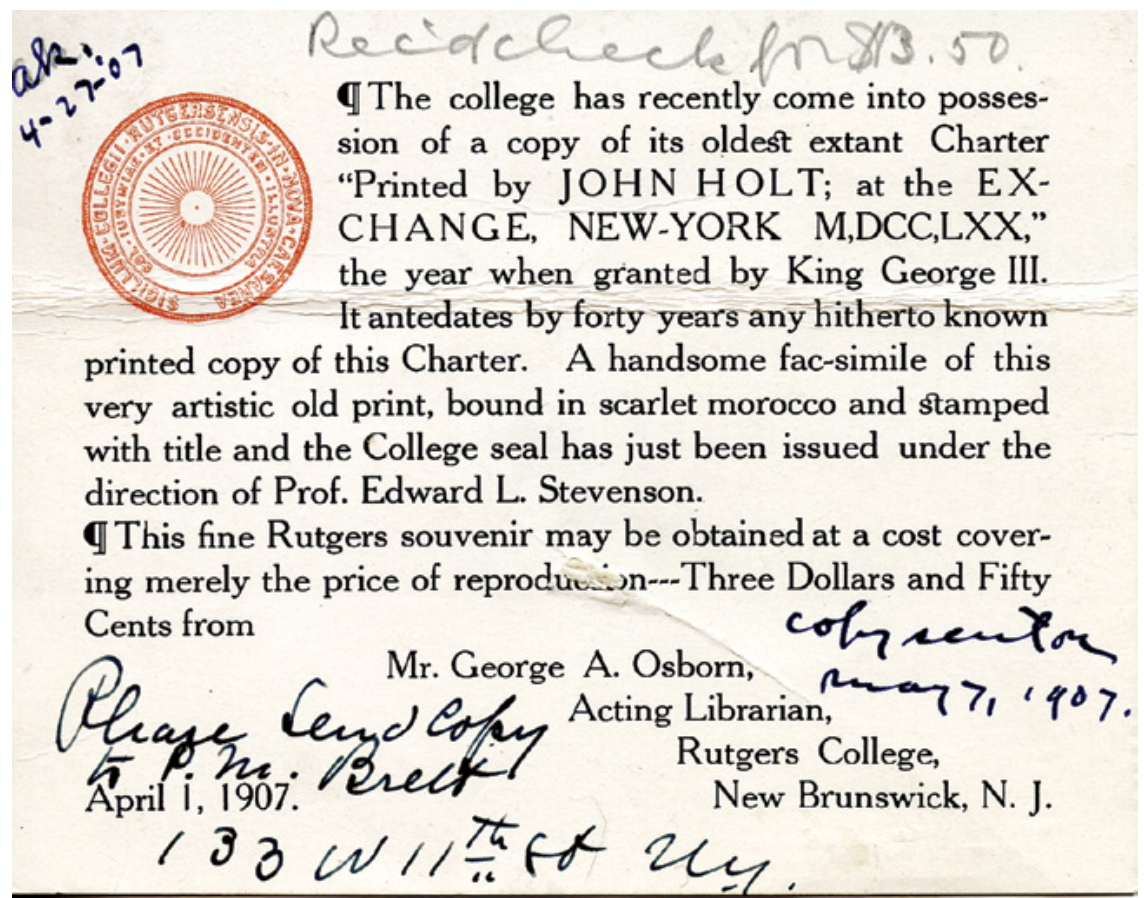

Advertisement for charter facsimile 
Presumably, it was one of these reproductions that Demarest held in his hand in his 1908 Charter Day speech.

The sale of the charter facsimiles met with more success and appreciation in some quarters than others. Demarest's correspondence contains thank you notes-one specifically mentioning how the reproduction, "printed on hand made paper, bound in red morocco, with the college seal tooled in gold on the cover...is now one of my treasures" 36 - and orders for copies of the charter. However, a letter from Charles E. Pattison, Class of 1884 indicated that he was reluctant to help advertise it at an alumni meeting. Regarding a copy of the charter and circulars advertising it, he said:

About all I can do with this is at some meeting to place it where the members can see it and this I shall be glad to do. I cannot, however, be responsible for its not being carried off or not being soiled, as I should not have time to watch it, and would not care to do so if I had. The Alumni rather resent having anything of this kind forced to their attention, and at the different dinners we have a number of times refused to let different publications be peddled to the members... ${ }^{37}$

Although the 1770 charter was the subject of an advertising campaign, the original charter remained a reference point for many years, up to the 150 th anniversary of Rutgers, which was specifically referred to as celebrating "the One Hundred and Fiftieth Anniversary of the Granting of the Charter" in materials about the celebration. ${ }^{38}$ However, in 1916, the administration thought that it was "inadvisable" to hold the 150th anniversary celebration on November 10, "being considered too late for anticipating favorable weather conditions" and held it in mid-October instead. ${ }^{39}$

\section{Conclusion}

As this article has shown, the Rutgers community did not always have knowledge of its own history, nor copies of its earliest charters. Although the original charter has never been found, despite searches at home and abroad, Rutgers owes its possession of the second charter to Samuel Smith Purple even though he had no direct association with Rutgers College. 


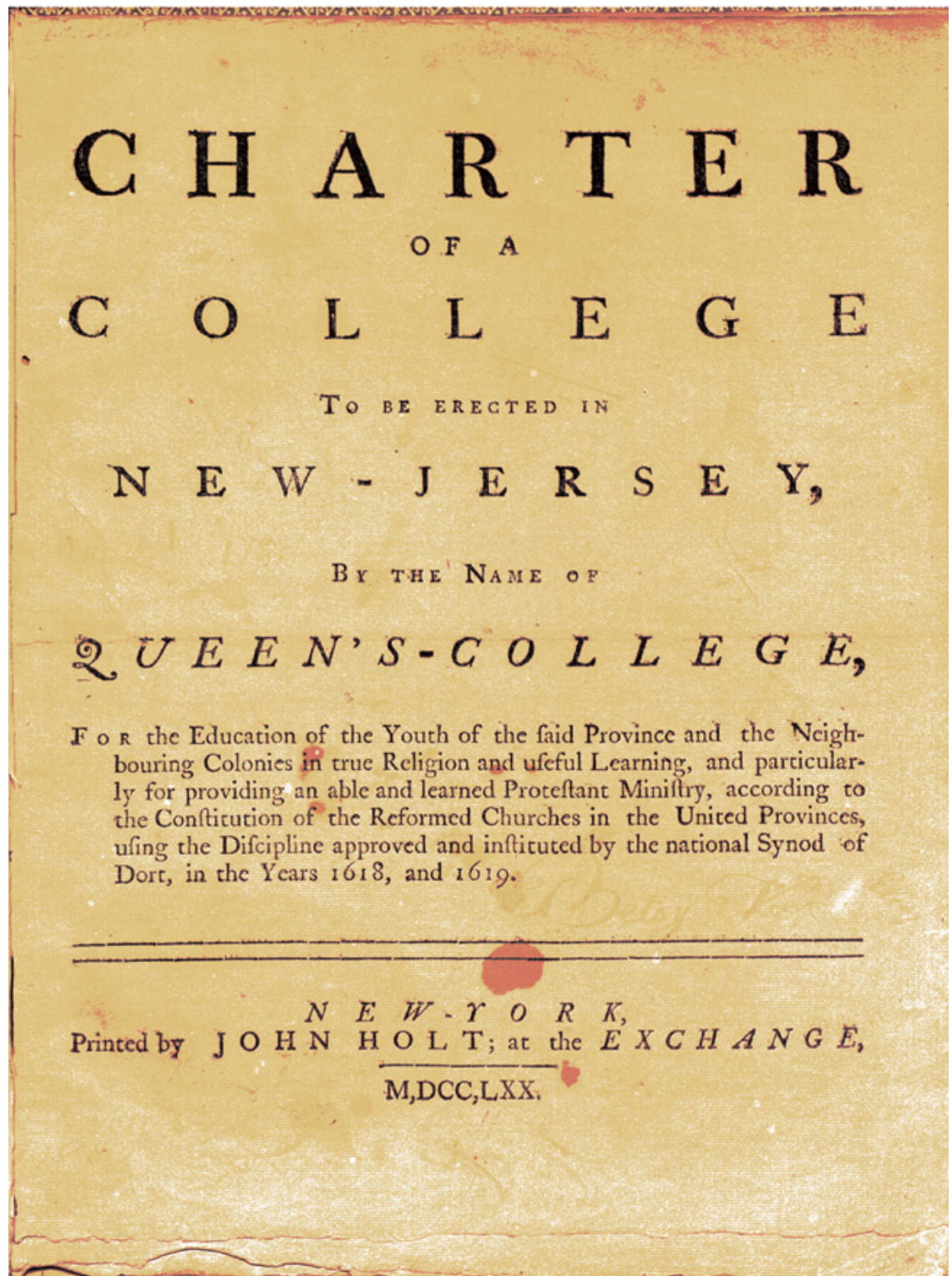

First page of the 1770 Queen's College charter

Once the founding date of Rutgers was known and verified, it became a source of pride for the college and began appearing on college materials, such as catalogs and yearbooks, and ultimately became celebrated as Charter Day. Rutgers took its place as the eighth colonial college. Although not the discoverer of the 1766 date, Austin Scott clearly played a role in authenticating the history of Rutgers and 
celebrating and promoting it. The impact can be seen in every 1766 that appears with the Rutgers name and the fact that 2016 is the year of the 250th anniversary celebration. The "wrong" centennial has become only an interesting footnote in the college's history.

Acknowledgements: I wish to thank my colleagues in Special Collections and University Archives, with special thanks to Tom Frusciano and Fernanda Perrone for their thoughtful comments on this article.

\section{NOTES}

1. "Rutgers College: Centennial Celebration at New Brunswick, N.J.Historical Discourse by Hon. Joseph P. Bradley-Meeting of the Alumni," New York Times (1857-1922); June 22, 1870; ProQuest Historical Newspapers, The New York Times, p. 5. Note: For this and subsequent quotations, punctuation and formatting and capitalization are taken from the sources and may not be consistent with other quotations or modern usage.

2. "Charter Day Addresses: The Charter and the Founders," The Targum XXIX, no. 8 (November 18, 1908), 176. I came across this speech in the course of my responsibilities at Special Collections and University Archives and reading it prompted me to do the investigation described in this article. As someone who has always known 1766, I was intrigued by the fact that the anniversary was celebrated the wrong year.

3. William H. S. Demarest, History of Rutgers College, 1766-1922. (New Brunswick, NJ: Rutgers University, 1924), 431-432. Richard P. McCormick's update, Rutgers: A Bicentennial History (New Brunswick, NJ: Rutgers, The State University, 1966), was equally matter-of-fact about the error, which was mentioned as: "Unaware that the College had received its first charter in 1766, the alumni and Trustees arranged to celebrate the centennial of the College in 1870, the anniversary of the second charter." (p. 101).

4. "Celebration at Rutgers College: Anniversary of the Granting of the Charter Observed," New York Times (1857-1922); November 11, 1895; ProQuest Historical Newspapers, The New York Times, p. 2. Scott is also referred to in the Rutgers Targum IX, no. 17, 193, (June 1, 1889) which opens with the words "According to the latest records discovered by Dr. Scott, the coming Commencement makes the 122 nd anniversary of the college." 
5. The University Magazine was published by the University Magazine company and was not affiliated with any educational institute. Its masthead indicates that it was "A special publication, identified with the general interests of all higher seats of learning, aiming to present an accurate and impartial reflection of all events and questions of the college world (Vol. 3, no. 1, p. 3).

6. F. Reid Miller, Letter to the Editor, February 7, 1890. The University Magazine 3, nos. 2-3 (March 1890), 82, https://books.google.com/ books?id=sF09AQAAMAAJ.

7. The wording here is confusing, but it is clear that 1766 is the date of the "true founding" and as indicated later in this article, changes in date from 1770 to 1766 were made around this time. The dormitory referred to is Winants Hall, which does feature 1766 carved in its stone.

8. Austin Scott, Letter to the Editor, February 1890, The University Magazine 3, nos. 2-3 (March 1890), 82, https://books.google.com/ books? id=sF09AQAAMAAJ.

9. As Scott indicated, these mentions occur in New Jersey Theological Seminary, Centennial of the Theological Seminary of the Reformed Dutch Church in America, (New York, Board of Publication of the Reformed Church in America, 1885). The section referred to is "Historical Discourses by Prof. David D. Demarest, D. D." so the attribution to Demarest is correct. Demarest's date of November 18 appears to be an error-the call from the New-York Mercury reprinted on 332 does indicate November 10.

10. Centennial, 76 and 342. It would seem that Rutgers had a copy of the contents of the 1770 Charter, but not an original printing.

11. See The University Magazine 3, no. 1 (January 1890), 39 and 3, nos. 2-3 , (March 1890), 83, https://books.google.com/ books?id=sF09AQAAMAAJ.

12. The Rutgers Targum IX, no. 17 (June 1889), 193.

13. See frontispiece, Rutgers College Catalog 1887-1888. The 1889 and 1890 Scarlet Letters are available at http://dx.doi.org/doi:10.7282/ T3TB14WP and http://dx.doi.org/doi:10.7282/T3WW7FM7 respectively.

14. The Rutgers Targum IX, no. 17 (June 1889), 194.

15. Ibid.

16. Rutgers Faculty Minutes, September 30, 1895, Volume 10, September 23, 1895-October 1, 1896, p. 7 
17. The hymn appears in The Targum XVI, no. 7 (November 13, 1895), 102. "Meribah" appears to be the short form for "The Waters of Meribah." The Charter Day program, including the hymn, is available online in the 1897 Scarlet Letter http://dx.doi.org/ doi:10.7282/T35B00DG, pp. 66-67.

18. The Targum XVI, no. 7 (November 13, 1895), 102-103.

19. Ibid., 103-104.

20. A copy of the 1769 petition and a transcription can be found in Queen's and Rutgers College Documents Relating to the Charter (RG 01/A) (hereafter called "Queen's and Rutgers College Documents"), Folder "Petition for Charter of 1770."

21. The Targum XVI, no. 7 (November 13, 1895), 102.

22. The Targum XX, no. 7 (November 10, 1899), 132. The Weston collection appears to have been place at Old Queen's and later moved to Voorhees Library and contained material relating to Napoleon I.

23. The Targum XXIII, no. 7 (November 13, 1902), 125.

24. The Targum XXV, no. 7 (November 17, 1904), 125.

25. "Austin Scott" The Targum XXVI, no. 17 (March 5, 1906), 327.

26. See page 2-3 of this article for quote where Demarest talks about the wrong date for the centennial.

27. "Charter Day Addresses: The Charter and the Founders, by William H. S. Steele Demarest" The Targum XIX, no. 8 (November 18, 1908), 177.

28. Ibid.

29. Ibid. The 1770 Charter was printed by John Holt. William Demarest later wrote an article about the Charter in which he gives more details about Purple. His account of the acquisition of the Charter differs slightly from 1908 version in that it says Rutgers learned about the Charter through an auction announcement. W.H.S. Demarest, "The Charter," The Journal of the Rutgers University Library 5, no. 1 (December 1941), 1-8, http://dx.doi.org/10.14713/jrul. v5i1.1187.

30. Dr. Purple's obituary is available at "Death List of a Day" New York Times (1857-1922); October 1, 1900; ProQuest Historical Newspapers: New York Times, p. 7. Another article about Purple's library is "Dr. Purple's Collection" New York Times (1857-1922); October 1, 1900 or October 13, 1900; ProQuest Historical 
Newspapers: New York Times, p. BR4; C. F. Libbie and Co's The Catalogue of the Genealogical Library of the Late Samuel S. Purple, M.D. ... To Be Sold at auction ... Feb. 16th to 19th, 1909 ... C.F. Libbie \& co., Auctioneers and Appraisers, Boston, Mass. ... (Boston, MA: C. F. Libbie, and Co., 1909) gives a brief biography and description of Purple's collecting activities and details over 2,000 items from Purple's library available through auction. Viewed online April 14, 2015 at https:// archive.org/details/catalogueofgenea00purp; Dr. Purple was also editor of Records of the Reformed Dutch Church in New Amsterdam and New York: marriages from 11 December, 1639 to 26 August, 1801 (New York, Printed for the Society, 1890).

31. Francis Harper to George Osborn, November 26, 1906, Bound into Rutgers copy of Rutgers University, Charter of a College to be Erected in New-Jersey, by the Name of Queen's College, (New York: Printed by J. Holt, 1770).

32. "Charter Day History," The Targum XXVIII, no. 8 (November 13, 1907), 150.

33. Correspondence to and from Shearer and North can be found in Queen's and Rutgers College Documents, Folder "Charter of 1766: Search for, 1907-1908, 1927." Another search undertaken by Rutgers librarian Alexander S. Graham in 1927 and detailed in the Rutgers Alumni Monthly of December 1927 (p. 66).

34. Anna M. North to George Osborn. Letter, June 18, 1907, Queen's and Rutgers College Documents, Folder "Search for Charter, 190708, 1927." Although the letter is addressed to "Esteemed Friend" other letters of the same vein are addressed to Osborn.

35. Advertisement for 1770 Charter Facsimile, April 1, 1907, Queen's and Rutgers College Documents, Folder "Reproduction of 1770 Copy, Distribution and Sales."

36. W. J. H. [last name undetermined] to Demarest, letter, March 3, 1909, Queen's and Rutgers College Documents, Folder "Charter, Reproduction of 1770 Copy, Distribution and Sales."

37. Charles Pattison to George C. Osborn, letter November 18, 1907, Queen's and Rutgers College Documents, Folder "Charter, Reproduction of 1770 Copy, Distribution and Sales."

38. 150th Anniversary Celebration Committee. Announcement. Demarest Papers, Box 6, Folder 18.

39. Demarest, History of Rutgers College, 530 and Rutgers College, The Celebration of the One Hundred and Fiftieth Anniversary of Its Founding As Queen's College, 1766-1916, (New Brunswick, NJ: Published by the College), 1917: 2. The 150th anniversary celebration was held October 13-15, 1916. 